\title{
Operational problems of tramway infrastructure in sharp curves
}

\author{
Wtodzimierz Czyczuta \\ wlodzimierz.czyczula@pk.edu.pl | (1D https://orcid.org/0000-0003-2774-1100 \\ Maciej Rochel \\ maciej.rochel@doktorant.pk.edu.pl | (1D) https://orcid.org/0000-0002-8109-973X \\ Cracow University of Technology, Faculty of Civil Engineering, Department \\ of Roads, Railways and Traffic Engineering
}

Scientific Editor: Andrzej Winnicki, Cracow University of Technology

Technical Editor: Aleksandra Urzędowska, Cracow University of Technology Press Language Verification: Timothy Churcher, Merlin Language Services

Typesetting: Anna Basista, Cracow

University of Technology Press

Received: July 22, 2021

Accepted: September 3, 2021

Copyright: @ 2021 Czyczuta, Rochel. This is an open access article distributed under the terms of the Creative Commons Attribution License, which permits unrestricted use, distribution, and reproduction in any medium, provided the original author and source are credited.

Data Availability Statement: All relevant data are within the paper and its Supporting Information files.

Competing interests: The authors have declared that no competing interests exist.

Citation: Czyczuta, W., Rochel, M. (2021). Operational problems of tramway infrastructure in sharp curves. Technical Transactions: e2021015. https://doi. org/10.37705/TechTrans/e2021015

\begin{abstract}
Elements of the tramway track that require special attention in the design and maintenance of the tramway infrastructure are sharp curves (curves with small radii). In such places, there are a number of unfavourable operational problems, which are discussed in the article below. It describes the characteristics of such geometric elements and analyses the interaction of the wheel-rail system. Moreover, the most important operational problems are presented, such as the wear of wheels and tramway rails, the buckling of the rails, and noise and vibrations occurring during the passage of the tram. Methods of reducing unfavourable phenomena occurring on curves in the tramway infrastructure were also highlighted.
\end{abstract}

Keywords. Tramway infrastructure, rail, sharp curve 


\section{Introduction}

Tramway tracks, due to their location in city centres, require compromises in their design and construction. Due to space limitations (distances from buildings, topography) and operational limitations (tramway rolling stock), the construction or reconstruction of a tramway line requires reconciling the interests of all users of public space (pedestrians, cyclists, drivers, etc.) in a given location. Therefore, at tramway terminals, junctions and depots, it is necessary to use curves with small radii in order to minimise the interference of the infrastructure with the surroundings areas.

\section{Characteristics of sharp curves}

There is no clear legal definition that states when there is a curve with a small radius. In accordance with the regulation on technical conditions to be met by public roads and their location, the radius of the curve of the tramway track should not be less than $50 \mathrm{~m}$ on the route and $25 \mathrm{~m}$ at the intersection, junctions and tramway terminals (Rozporządzenie Ministra Transportu i Gospodarki Morskiej z dnia 2 marca 1999r. w sprawie warunków technicznych, jakim powinny odpowiadać drogi publiczne i ich usytuowanie (Dz. U. 1999 nr 43 poz. 430 z późn. zm.). However, in the optional document, the Technical Guidelines for the Design, Construction and Maintenance of Tramway Tracks from 1983, it was stated that the recommended curve radius should be at least $150 \mathrm{~m}$ on the route, and no less than $25 \mathrm{~m}$ at crossings and junctions, while in depot tracks, the minimum should be $20 \mathrm{~m}$ (Wytyczne techniczne projektowania, budowy i utrzymania torów tramwajowych, 1983). It should be emphasised that the provisions of the regulation (Dz. U. $1999 \mathrm{nr} 43$ poz. 430 z późn. zm.) apply only to the tramway infrastructure located in a public roads, so it is possible to make a curve within the tramway depot with a radius specified by the infrastructure manager, most often based on the technical conditions of the operated rolling stock. Therefore, it can be assumed that sharp curves are those for which the radius is not more than $50 \mathrm{~m}$.

Very often, curves with a small radius are located on sections of tramway networks with a high frequency of vehicles - at junctions or entrances and exits from the depot. Generally, trams are relatively light and have low axle loads (well below $100 \mathrm{kN}$ ). However, the high frequency of vehicles running on a given section of the track may result in an annual transport load (reaching even $10 \mathrm{Tg} /$ year) comparable with the load on a secondary railway line (Oleksiewicz \& Kraśkiewicz, 2013).

A tramway passage of a sharp curve is usually performed at a low speed of $10-20 \mathrm{~km} / \mathrm{h}$. In addition, vehicles stop at tramway terminals and within junctions, so trams stop and start on curves. Additionally, on curves with small radii, the tramway rolling stock significantly affects the track, which causes its accelerated degradation and the deterioration of comfort for passengers (Czyczuta \& Wajer, 2015). Therefore, sharp curves are critical sections on the tramway network and are most exposed to the breakdowns and derailments of vehicles, and in such places, special attention should be paid to safety issues during the operation of the infrastructure.

\section{Analysis of the wheel-rail system on sharp curves}

The wheel-rail system (i.e. the contact of the tramway wheel with the rail) significantly affects safety, travel comfort and the wear of friction elements through the geometry of the wheel rim and rail profile, the location of the contact between them and the forces that occur on it.

In accordance with the recommendations described in the guidelines (Wytyczne, 1983), grooved rails should be used in sharp curves. Currently, the 


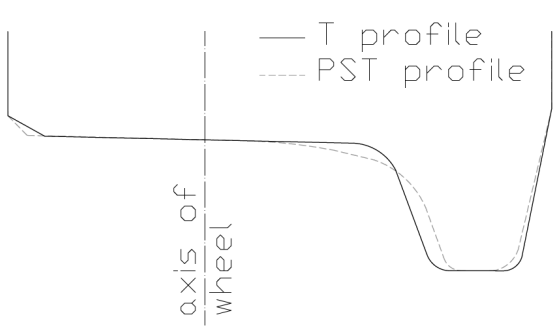

Fig. 1. Comparison of T and PST profiles, own elaboration based on (PN-91-K-8825, 1991) most popular profile of the grooved rail in Poland is type 60R2. This type of rail is an asymmetrical rail, and its head is profiled with a tilt of 1:40 towards the inside of the track.

There are two types of tramway wheel rim profiles: T and PST. The T-type profile is an older solution, while the PST profile is its improved version, based on the wear analysis of its prototype. The PST profile was designed and implemented at the end of the $20^{\text {th }}$ century for the purposes of the Poznan Fast Tram (Staśkiewicz \& Nowakowski, 2016). The profiles differ mainly in the shape and position of the flange. In the PST profile, the dimension of the guide length is selected so that the gap between the rail and the flange is $5 \mathrm{~mm}$, while for the T profile, it is $2.5 \mathrm{~mm}$.

The essential elements of the running surface of a tramway wheel are the tread and the flange. In the straight section, the point of contact between the running surface and the rail is a single point. This contact carries the vertical loads of the wagon. On a horizontal curve with a small radius in the wheel-rail system, the horizontal (centrifugal) force also begins to act, which causes the contact between the wheel and the outer rail to be on two points - the rail head contacts the tread and the flange of the overlapping wheel in the side part. On the inner rail, however, the contact of the wheel with the rail remains a single point.

Figure 2 shows the shape of

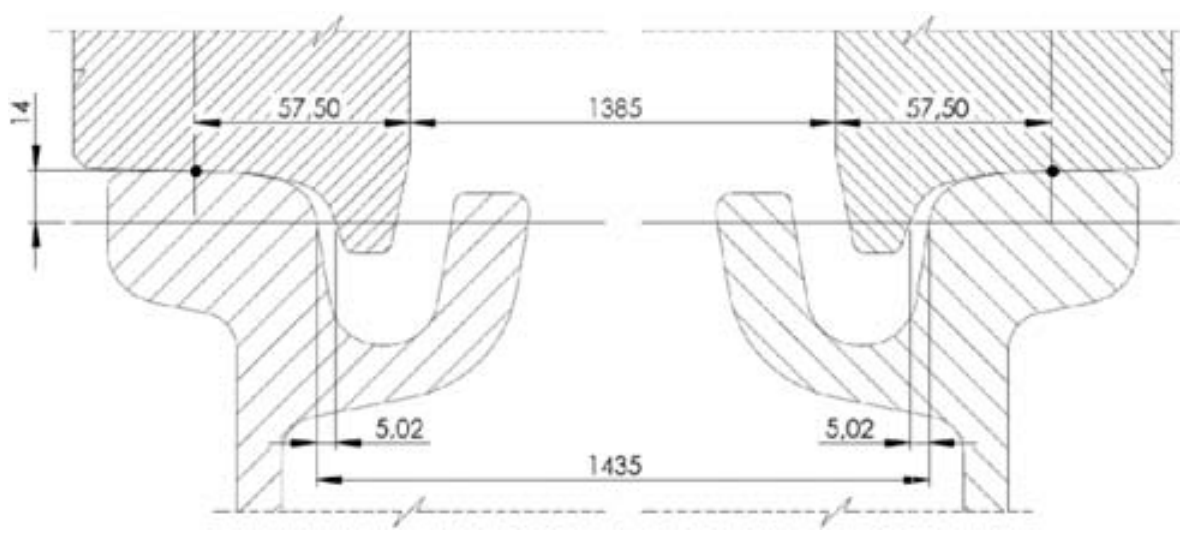

Fig. 2. Points of contact of wheel profiles with rails on the straight line (Staśkiewicz \& Nowakowski, 2016)

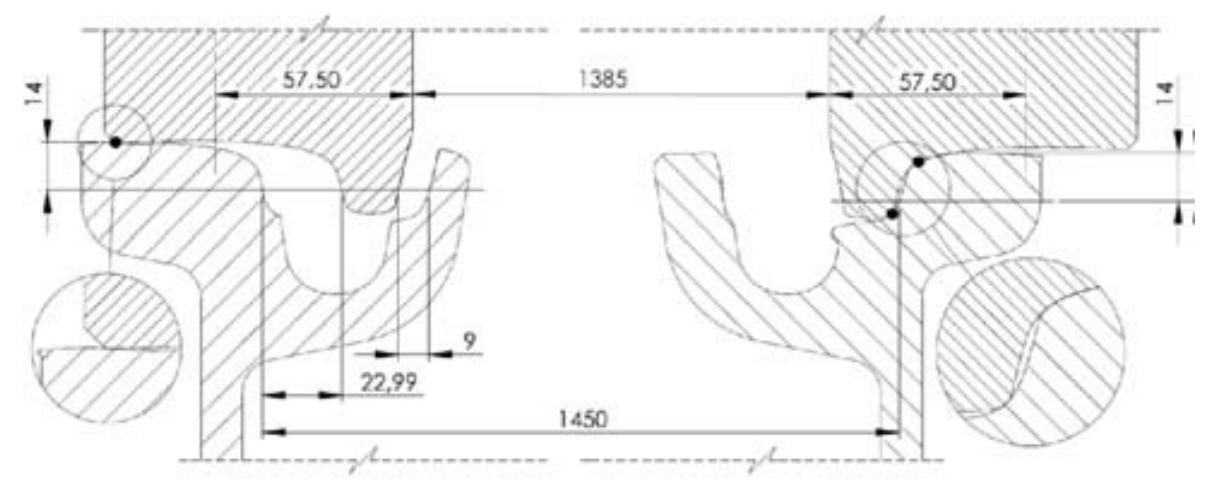
the wheel-rail system on a straight section in a situation in which the infrastructure is relatively new and in good technical condition.

In the curve, the gap between the check on the inner rail and the flange of the inner wheel decreases with increasing wear of the side of the outer groove rail head and the rim of the wheel. In the limit state, the phenomenon of the two-point contact of the wheel with the rail also occurs on the inner rail track. After exceeding the critical value, the edge of the rail wheel may climb onto the rail, which may result in derailment (Grulkowski, 2009). Figure 3 shows how the contacts run in the wheel-rail system on the worn track. The track is located in the left horizontal curve with a radius of $\sim 25 \mathrm{~m}$. The right rail is the outer rail.

The shaping of the rail head should ensure that the wheel profile is adjusted to the rail in such a way that the contact is a single point. The conical shape of the tramway wheel raceway determines the shape of the rail head. Therefore, nowadays rails are used with an inclination of

Fig. 3. Points of contact of wheel profiles with rails in the curve in the case of significant rail wear (Staśkiewicz \& Nowakowski, 2016)
1:40 inwards, which corresponds to the inclination of the wheel tread. Such an adjustment of the system enables the axial transfer of loads and minimises the wear of the tramway wheels (Grulkowski \& Zariczny, 2012).

The type of boggie carriages is also an important aspect in the analysis of the wheel-rail system of a small radius curve. The three most popular boggie designs in terms of wheel guidance are as follows:

- boggies with classic wheelsets, in which the wheels are connected with an axle; 
- boggies with portal axles, where the axis connecting the wheels is vertically shifted in relation to the centre of the wheels;

- boggies with virtual axles, where there is no physical connection between the axle between the wheels, and each wheel has an individual drive and forcing control ensuring a central position of the boggie in the track.

A classic wheelset on a curve with a small radius loses self-steering and the phenomenon of skidding of one of the wheels occurs, because even with the maximum displacement of the wheelset from the track axis, it is not possible to obtain the required differences in the rolling diameters of the wheels resulting from the rolling radius on the wheels of the set. Due to this phenomenon, the tire relaxation angle increases, and thus accelerates the wear of the wheel and rails (Rychlewski et al., 2017). There is no such problem in wheelsets with virtual axles because the wheelset does not slip due to the adjustment of the rotational speed of the wheels. The drive system control systems are responsible for speed regulation.

\section{Operational problems}

The aspects of the wheel-rail interaction presented in the previous section result in a number of unfavourable operational problems in sharp curves; these are presented in the following sections.

\subsection{Wear of tramway wheel}

The wheels of the tram in the wheelsets wear out with the distance travelled. It is estimated that the durability of the wheel rim (which is a friction element) is around $80,000-120,000 \mathrm{~km}$, depending on the type of tramway boggie and the rolling stock (Zając \& Jurga, 2009). After exceeding the wear limit, the rim is reprofiled so that it can be further used without the need to replace it.

The wear of tramway wheels occurs at their point of contact with the rail (i.e. on the rolling surface and the flange) and the wear limits are defined by the standard (PN-K-92016, 1997). The maximum allowable difference in wheel diameter is $10 \mathrm{~mm}$, while within one wheelset, this difference should not exceed $2 \mathrm{~mm}$. In terms of safety, the most important standard dimensions are the thickness of the flange, its height and the thickness of the rim (Kwaśniowski et al., 2017).

On a sharp curve, the flange of the wheel is exposed to significant transverse forces, which causes its accelerated wear. As the analyses show, the wear of the flange is clearly dependent on the radius of the arc (the smaller the radius of the horizontal curve, the greater the wear of the element). However, the wear of the wheel tread in the curves is less visible, although a certain relationship can also be observed (Opala, 2015).

It can also be stated that in trams that go around curves in a specific direction (right or left) significantly more frequently than in the other direction, the effect of uneven wear of the flange arises. For the rim that traverses the curves on the inner rail track more often, the extreme edge of the running surface is worn, while the rim from the outer rail track is characterised by wear of the wheel flange.

Significant deformation of the periphery also occurs when the wheel passes through the shallow-grooved frog of the turnout, where the vehicle wheel runs along the flange on a frog. It then takes on all the pressure of the vehicle. Therefore, the aspect of wheel-flange wear is crucial in assessing the overall wear of the rim and qualifying the element for replacement or re-profiling.

\subsection{Wear of tramway rail}

On sharp curves, there is an increased impact from the passing rolling stock on the tramway track. Its characteristic feature is the intensive wear of the rails on the curves, mainly on the external rail but also on the internal rail. The wear 


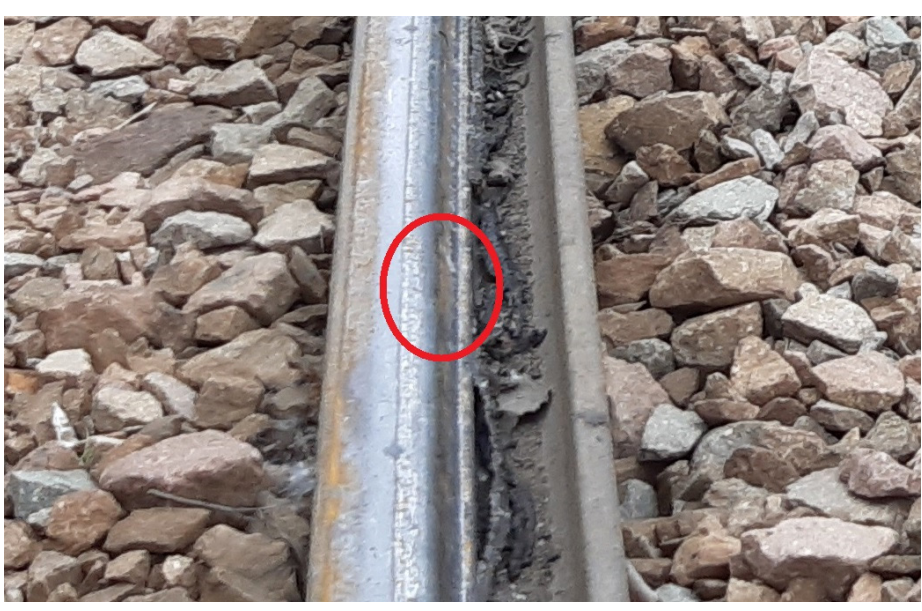

Fig. 4. Lateral wear of the outer rail head on a curve with a radius of $30 \mathrm{~m}$ (red - worn part of the rail) [own study]
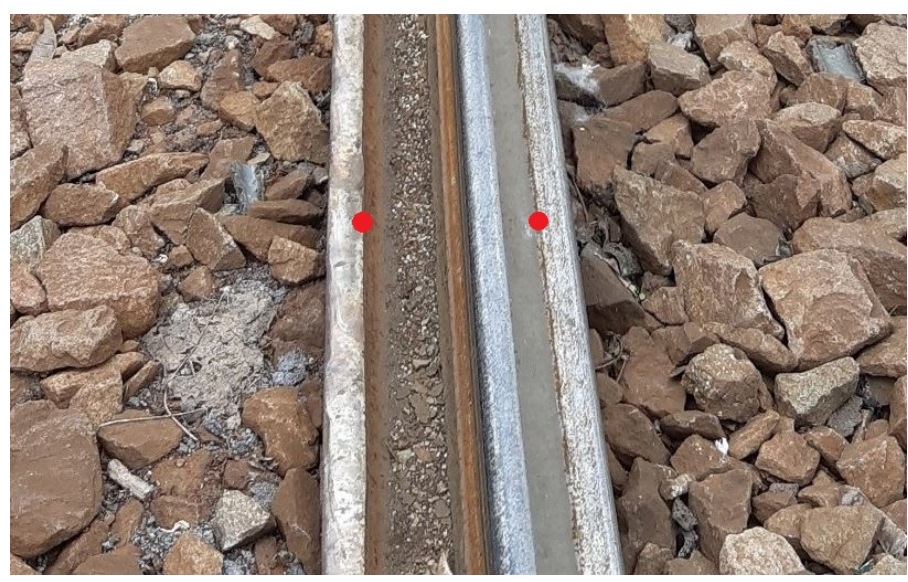

Fig. 5. Vertical wear of the inner rail head and the check on a curve with a radius of $30 \mathrm{~m}$ (red - places of two-point contact) [own study]

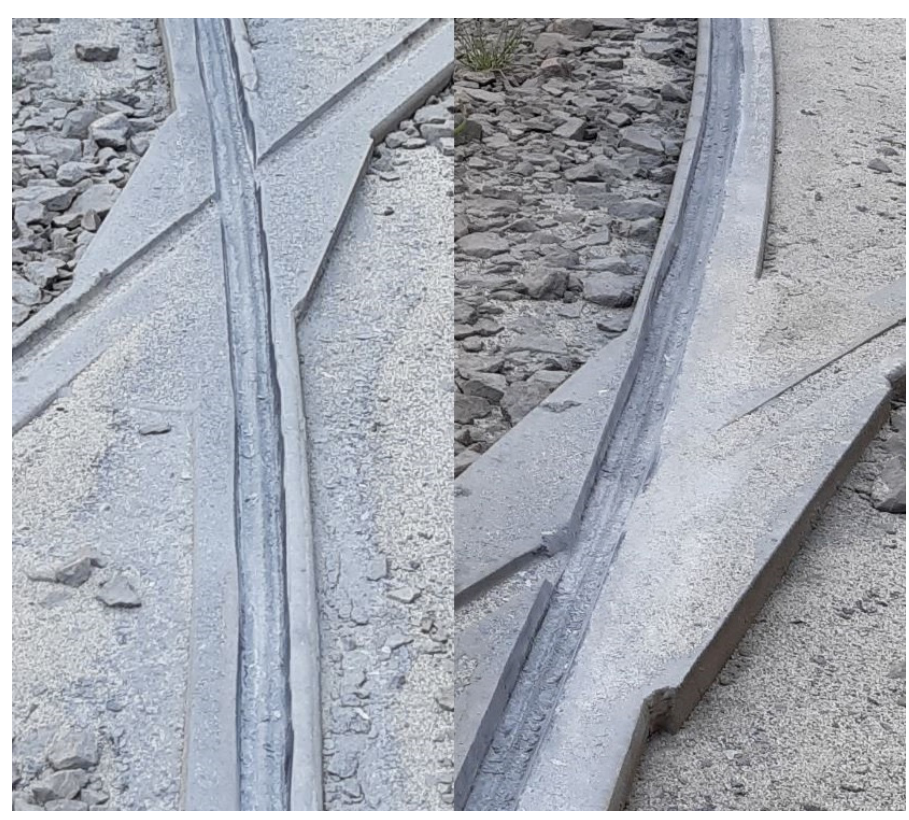

Fig. 6. Wear of a frog element and closure rails on a curve with a radius of $20 \mathrm{~m}$, on the left - fracture of the left railroad, on the right - fracture of the right railroad [own study] process of rails on curves depends on the radius of the curve and the load on a given section of the tramway network. The smaller the radius of the curve, the more rapid the wear process (Grulkowski, 2009).

The condition of the rails is assessed on the basis of measuring the vertical and horizontal wear of the rail heads. In accordance with the provisions of the guidelines (Wytyczne, 1983), the permissible vertical wear of the rail head is $18 \mathrm{~mm}$, while the side wear should not exceed $15 \mathrm{~mm}$. However, in another part of the document (Wytyczne, 1983), it was specified that on curves with a radius of less than $100 \mathrm{~m}$, the track width should not be greater than $1450 \mathrm{~mm}$. It follows that for tramway tracks with a standard gauge $(1435 \mathrm{~mm})$, the permissible side wear should not exceed $15 \mathrm{~mm}$ for both rails. However, the regulations (Wytyczne, 1983) do not specify the limit wear values of the checks in the groove rail.

As shown by the analysis of the wheel-rail system, the wear of the rails on the curves is gradual. After the track is put into operation, the outer rail wears out. Under the influence of passing trams, the side of the outer rail head is worn by the flange of the wheel. The described situation is shown in the Figure 4.

In the next stage of operation, after reaching the wear limit of the outer rail, the phenomenon of two-point contact of the tramway wheel on the inner rail occurs. This leads to progressive wear of the check on the inner rail, which may lead to a derailment when it is in a critical condition. Figure 5 shows a fragment of the inner rail on a small radius curve.

The tramway infrastructure wear and tear on small radius curves also occurs within the tramway junction, where the vehicle wheel runs along the flange on a frog.

Figure 6 shows the significantly worn-out shallowgrooved frogs of a tramway turnout. Two traces of the flange of the wheel are visible where the groove is shallow. Also the undulating nature of the wear of the closure rail check and significant amounts of sand from tramway sandboxes are visible on the figure.

On a sharp curve with a radius of $20 \mathrm{~m}$, the tramway boggie is positioned obliquely in the track and the phenomenon of snaking occurs, which makes it possible to observe the undulating nature of the wear of the track components (Grulkowski \& Zariczny, 2015). Two traces of the flange of the wheel result from the different travel paths of the trailer boggie and the loco boggie. However, the wheel slip resulting from the difference of the rolling radius on the rails causes the tramway systems to detect the lack of adhesion (different rotational speeds of the wheels) and apply sand from the sandboxes.

\subsection{Tramway rail buckling}

Another operational problem of the infrastructure on small radius curves is the buckling of the tramway track.

Currently, most tramway tracks are made using continuous welded rail track (CWR) technology, where 
the rails are joined using thermite joints (Czyczuta, 2002). A properly constructed and maintained track in this technology should be resistant to thermal stresses which constitute an additional load on the structure of the tramway surface. The horizontal force from thermal stresses arises because the rail lengthens or shortens under the influence of temperature changes. In a CWR track, this force cannot be compensated by rail joints, as it is in the case of a classic track with splice joints. If the thermal stresses are too high, such a track may buckle.

In a CWR track, particularly important parts of the track are places with increased operational loads (braking and acceleration of vehicles) and places of inhomogeneity in the structure of tramway surfaces (at crossings, turnouts, etc.) (Towpik, 2016). In such locations, the probability of the occurrence of buckling in the path is higher. Buckling most often occurs due to manufacturing and design errors, and due to improper diagnostics of the contactless track (Bujak et al., 2017).

Figure 7 shows the buckling of a CWR track at the contact point of the cross-section change from grooved rail (60R2) torailway rail (49E1). By contrast, Figure 8 shows buckling of the tramway rail visible in the right rail track at the junction of the classic (ballast) surface with the tramway track surface made of prefabricated concrete slabs (ballastless track). The visible buckling is due to the threshold effect resulting from the change in surface stiffness (Sotkowski, 2009). To counteract this phenomenon, transition zones can be used, but they are not justified in tramway infrastructure. The solution to this problem is the appropriate design of locations of the change of surface type so that such buckling does not occur on the curves.

\subsection{The noise and vibration of the tramway crossing}

Noise and vibrations occur during tramway rides as a result of tribological processes taking place in the wheel-rail system (Zariczny \& Grulkowski, 2009). Such an impact of infrastructure in the vicinity of the route has a negative impact on people and the environment.

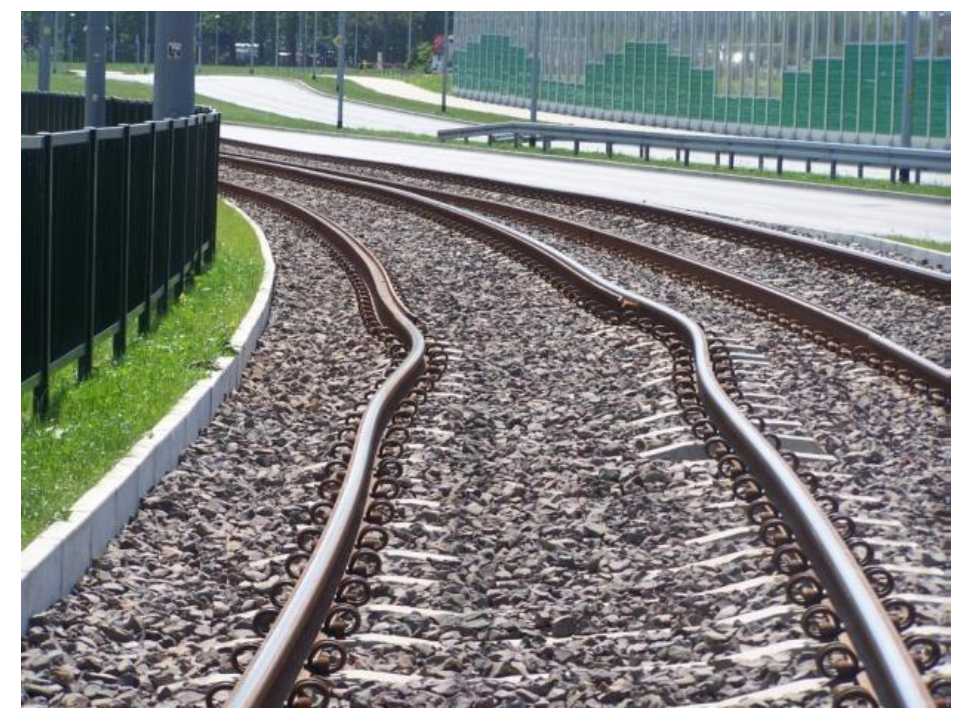

Fig. 7. Buckling of a tramway track where the rail cross-section changes (Bujak et al., 2017)

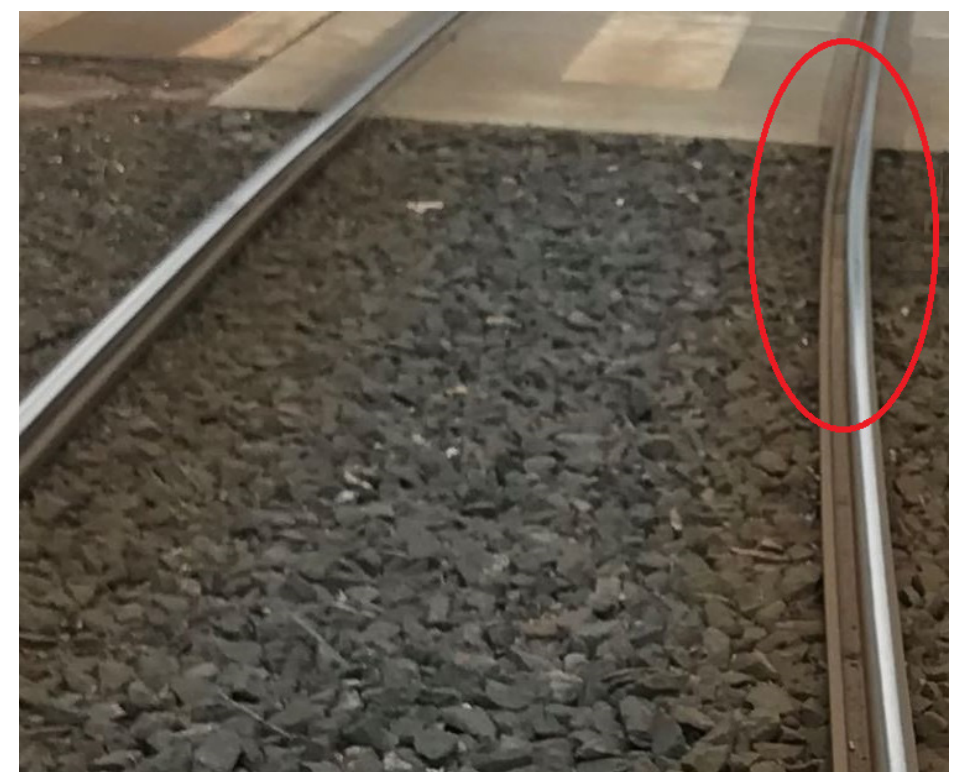

Fig. 8. Buckling of a tramway track (red) - change of the tramway track surface type from ballast track to track on a concrete slab [own study] Therefore, efforts are made to reduce noise and vibrations during the passage of trams.

For low speeds below $50 \mathrm{~km} / \mathrm{h}$ on straight sections, the main source of noise is the vehicle and its engines (Szabtowska \& Rochel, 2020). However, in a small radius curve, the following elements are sources of noise (squeaks and vibrations) (Zariczny \& Grulkowski, 2009):

- friction of the outer wheel flanges against the side surface of the rail head;

- longitudinal slip between wheels mounted on a common axle due to different rolling radii on the wheels of the set;

- lateral creep of the running surfaces of the wheels running on the rail heads.

A number of preventive measures can be taken to reduce the negative impact of infrastructure on the environment. In tramway infrastructure, these are (Szabłowska \& Rochel, 2020): 


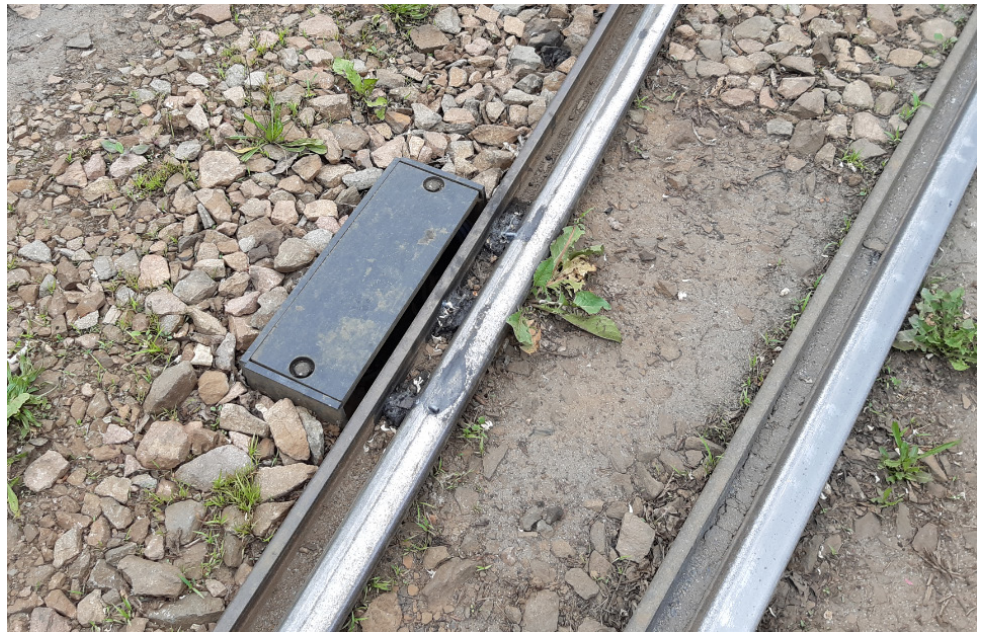

Fig. 9. Track lubricator on the closure rail in the tramway junction [own study]
- lubrication of tramway wheel rims;

- lubrication of the running surface or groove of the tramway rail;

- use of ballastless slab tramway surface filled with crushed stone or soil with grass (or sedum). The lubrication of rails and wheel rims is aimed at reducing the value of the coefficient of friction in the wheel-rail system, as a result of which, apart from reducing noise, the wear of friction elements in the tramway (rims) and infrastructure (rail heads) is also reduced (Zariczny \& Grulkowski, 2009). The rails are lubricated with lubricants or friction modifiers. Most often, grooved rails used in small radius curves are lubricated through a hole in the rail head or in its groove. The method of application depends on local conditions.

As research (Szabłowska \& Rochel, 2020) shows, the lubrication of the running surfaces of rails can reduce the noise level by several decibels.

The efficiency of lubricators primarily depends on the type of rolling stock (mass and speed) and the location of the curve, as well as the track lubricators themselves.

\section{Conclusion}

Small radius curves and tramway turnouts are critical elements on the tram network, the reliability and durability of which determine the safety of this means of transport. Due to the specificity of the wheel-rail system at sharp curves, there are many unfavourable operational problems, such as:

- wear of tram wheels;

- wear of tramway rails and turnout elements;

- buckling of tramway tracks;

- the occurrence of noise and vibrations on the curve during the passage of the tram.

The discussed operational problems have a significant impact not only on the infrastructure and rolling stock but also on the environment and travel comfort for passengers. In order to counteract these phenomena, it is necessary to constantly monitor and maintain the tramway infrastructure in a proper condition, as well as to apply preventive measures such as track lubricators.

In addition to caring for infrastructure and rolling stock, at the national level, it is also necessary to take into account the need to update the existing regulations on the design and construction of tramway infrastructure so that they comply with today's standards (Rochel, 2019).

Undoubtedly, in the coming years, the development of the structure of tramway tracks and rolling stock will enable the reduction of unfavourable phenomena occurring at sharp curves.

\section{References}

Bujak, N.,Grulkowski,S., \&Zariczny,J.(2017).Aspektybezpieczeństwawprojektowaniu i budowie infrastruktury tramwajowej. Archiwum Instytutu Inżynierii Lądowej, 25, 87-105. https://doi.org/10.21008/j.1897-4007.2017.25.07

Czyczuta, W. (2002). Tor bezstykowy. Kraków: Wydawnictwo PK.

Czyczuta, W., \& Wajer, R. (2015). Problemy eksploatacji torowisk tramwajowych. Zeszyty Naukowo-Techniczne Stowarzyszenia Inżynierów i Techników Komunikacji w Krakowie, 95 (Seria: Materiaty Konferencyjne). 
Grulkowski, S. (2009). Charakterystyka bocznego zużycia szyn w tukach torów tramwajowych. Technika Transportu Szynowego, R. 15 (nr 7-8=182-183), 84-87.

Grulkowski, S., \& Zariczny, J. (2015). Charakterystyka zużyć, wad i uszkodzeń szyn w torach tramwajowych. Zeszyty Naukowo-Techniczne Stowarzyszenia Inżynierów i Techników Komunikacji w Krakowie, 2 (106).

Grulkowski, S., \& Zariczny, J. (2012). Znaczenie dopasowania uktadu koto-szyna w transporcie tramwajowym - przegląd doświadczeń. Technika Transportu Szynowego.

Kwaśniowski, S., Restel, F., \& Wolniewicz, F. (2017). Problemy zużycia szyn i kót tramwajowych w warunkach wroctawskich. Prace Naukowe Politechniki Warszawskiej, 115.

Oleksiewicz, W., \& Kraśkiewicz, C. (2013). Rozwój konstrukcji i układu geometrycznego torowisk tramwajowych, jako istotny element postępu w miejskim transporcie szynowym. Zeszyty Naukowo-Techniczne Stowarzyszenia Inżynierów i Techników Komunikacji w Krakowie, 3-102 (Seria: Materiaty Konferencyjne).

Opala, M. (2015). Symulacyjne badania zużycia profili kót tramwaju poruszającego się w tukach o małych promieniach. Logistyka, 4.

Rochel, M. (2019). Nowoczesne rozwiązania zzakresu infrastruktury tramwajowej na przykładzie Krakowa w świetle tramwajowych przepisów budowlanych. Wspótczesne Problemy Transportu, 6 (Infrastruktura transportu), 48-62. https://repozytorium.biblos.pk.edu.pl/resources/42025

Rychlewski, J., Firlik, B., \& Straszewski, W. (2017). Wytyczne projektowania torów tramwajowych a obecnie używany tabor tramwajowy. Archiwum Instytutu Inżynierii Lądowej, 335-355. https://doi.org/10.21008 /j.1897-4007.2017.25.26

Sołkowski, J. (2009). Zarys analizy efektu progowego przy tączeniu nawierzchni podsypkowych z innymi typami nawierzchni. Technika transportu szynowego, 12.

Staśkiewicz, T., \& Nowakowski, T. (2016). Analiza wspótpracy kota tramwajowego z szyną w warunkach rzeczywistej eksploatacji. Problemy Kolejnictwa, 171.

Szabtowska, P., \& Rochel, M. (2020). Ways of protection from noise pollution in railway and tramway infrastructure. Journal of Civil Engineering and Transport, 2(1), 35-45. https://doi.org/10.24136/tren.2020.003

Towpik, K. (2016). Tor bezstykowy - zagrożenia, diagnostyka, utrzymanie. Prace naukowe Politechniki Warszawskiej, Transport, 114.

Zając, G., \& Jurga, S. (2009). Badania trwałości obręczy kót tramwajowych eksploatowanych w MPK S.A. w Krakowie. Problemy eksploatacji, 2.

Zariczny, J., \& Grulkowski, S. (2009). Efektywność dziatania smarownic a redukcja hatasu generowanego na tukach linii tramwajowych, Technika Transportu Szynowego, 9.

Norma PN-K-92016 Tramwajowe zestawy kołowe, elastyczne. Obręcze obrobione, Wymagania i badania, 1997.

Norma PN-91-K-8825 Zestawy kotowe taboru, tramwajowego. Kontur bieżni kót elastycznych wagonów tramwajowych, 1991.

Rozporządzenie Ministra Transportu i Gospodarki Morskiej z dnia 2 marca 1999r. w sprawie warunków technicznych, jakim powinny odpowiadać drogi publiczne i ich usytuowanie (Dz. U. 1999 nr 43 poz. 430 z późn. zm.).

Wytyczne techniczne projektowania, budowy i utrzymania torów tramwajowych, MAGTiOŚ, Warszawa 1983. 